\title{
URGENSI PENGELOLAAN KELAS; SUATU ANALISIS FILOSOFIS DAN PEMAHAMAN DASAR BAGI KALANGAN PENDIDIK DI PESANTREN
}

\begin{abstract}
:
Oleh: Djuwairiyah

Moh. Nawafil

Email:

Djuwairiyah.fawaid@gmail.com

Moh.nawafil.98@gmail.com

Universitas Ibrahimy

Technological development and globalization flow have got change rapidly from one sector to another sector. That matter becomes a vital indicator to Pesantren for upgrade and keeping the qualities of graduates. So that many efforts do to provide militant, integrity, clever, and creative cadres who can give a buge contribution to the development of Indonesia country. Lesson activity that made more active and communicative can stimulate student to have enthusiasm, motivation, and concentration to get the goal of learning. One of the important competencies that have to owned by teacher based on the two ways communication paradigm is class management. Class management is a systematic and structured effort to get the goal of learning activities. The urgency of class management for the teacher in pesantren caused it can provide student to get actual work in thinking, interaction, and argue abilities.
\end{abstract}

Keywords: Class Management, Teacher, Pesantren.

\section{PENDAHULUAN}

Pendidikan adalah salah satu hal yang paling urgen dalam proses atau laju kehidupan manusia. Hampir kesemua manusia yang berada dalam belahan bumi ini sepakat bahwa pendidikan merupakan tombak untuk memberantas penyakit kemiskinan dan ketimpangan eknomi. Banyak negara-nagara maju di dunia yang nyaris bila ditelisik dari sektor pendidikannya hampir tidak ditemukan defisit atau carut marut. Pendidikan menjadi tolok ukur esensial jika hendak melihat atau pun mengetahui seberapa maju dan berkualitasnya suatu negara. Pun sebaliknya, beberapa negara berkembang dan negara yang tergolong miskin memiliki kompleksitas masalah pendidikan yang tidak kunjung menemukan solusi, biasanya pula cenderung berlarut-larut.

Hal semacam di atas berjalan searah dengan statemen Siti Murtiningsih bahwa "karena pendidikan masyarakat maju, begitupula pendidikan yang maju hanya dapat ditemui dalam masyarakat yang maju." Jadi, bila suatu masyarakat telah berada pada

\footnotetext{
${ }^{1}$ Siti Murtiningsih, Pendidikan Sebagai Alat Perlawanan: Teori Pendidikan Radikal Paulo Freire, (Yogyakarta: Resist Book, 2004), 11.
}

singgasana kemajuan dalam segala aspek, maka lumrah dipastikan bidang pendidikannya tidak jauh berbeda dengan apa yang sedang dialami. Seiring berjalannya waktu masyarakat telah memahami betapa pentingnya pendidikan bagi kehidupan mereka atau pun buah hati mereka. Sehingga saking pentingnya pendidikan dalam benak masyarakat, maka institusi pendidikan setiap tahun menjadi pusat pemburuhan masyarakat untuk putra-putrinya agar mendapatkan tindakan berupa pembelajaran dengan sebaik mungkin. Sehingga nantinya mempunyai kemudahan akses guna meraih hidup bahagia dan berkecukupan. Jadi, sesuailah definisi pendidikan yang diutarakan oleh Aristoteles bahwa tujuan pendidikan adalah kebahagiaan. ${ }^{2}$

Tentunya dalam mejalankan pendidikan agar peserta didik nantinya bisa hidup bahagia tidaklah gampang. Perlu adanya kompleksitas rangkaian proses dan usaha. Adapun kesemua itu diantaranya adalah memberikan instruksi dan bimbingan kepada siswa untuk belajar dalam suatu media atau tempat tertentu. Salah satu tempat yang menjadikan sebuah

\footnotetext{
${ }^{2}$ Jalaluddin dan Abdullah Idi, Filsafat Pendidikan: Manusia, Filsafat dan Pendidikan, (Depok: Raja Grafindo Persada, 2016), 74 .
} 
proses interaksi antara guru dan murid sehingga tercipta sebuah pembelajaran yakni di dalam kelas. Dalam pengertian yang genaral bagi setiap orang akan sebuah kelas, seringkali diartikan sebagai suatu indikator-indikator kecil dalam bangunan sekolah.

Oleh karenanya seorang guru atau pun calon guru perlu memahami cara-cara pengelolaan kelas, dengan tujuan supaya proses pembelajaran dapat terjadi secara maksimal, efektif, menyenangkan. Ketika lingkungan belajar sudah kondusif, maka disitulah proses pembelajaran akan efektif dan menyenangkan. Ketika proses pembelajaran sudah bisa dikatakan baik, maka dengan sendirinya peserta didik akan senang belajar. Jika peserta didik senang belajar, maka kita akan hanya bisa melihat betapa majunya pendidikan di Indonesia.

Pendidikan yang telah maju, banyak melahirkan manusia yang cerdas berfikir dan mampu menciptakan sesuatu yang berarti bagi proses kehidupan. Akan tetapi realitas saat ini membuktikan bahwa masyarakat, khususnya masyarakat Indonesia mengalami dekadensi moral atau akhlak hampir pada semua segmen kehidupan dan seluruh lapisan masyarakat. ${ }^{3}$ Banyak bukti yang menandakan bahwa rusaknya moral di Indonesia telah terjadi, salah satunya adalah adanya praktik Korupsi, Kolusi, Nepotisme (KKN) di kalangan elite pemimpin kita. Berdasarkan Indeks Prestasi Korupsi pada tahun 2012 lalu, praktik KKN di Indonesia mengalami peningkatan 3\% secara kontinyuitas. Sementara pada tingkat rakyat, kerusakan moral banyak ditandai dengan terjadinya pencopetan, kekerasan, pencurian, aksi begal, penipuan dan lain sebagaiya. Pada ranah sekolah, baik itu formal maupun non formal, banyak kerusakan moral yang terjadi seperti seks pranikah (intercose before married) sekitar 18,4\% dari 385 remaja. ${ }^{4}$

Sebab demikian, maka peran pesantren sebagai lembaga pendidikan tertua dan mempunyai akar historis yang kompleks dalam wadah ke-Islaman, sangat berguna untuk menyelamatkan dekadensi moral dan carut marut akhlak serta menanamkan pemahaman yang menyeluruh kepada generasi

\footnotetext{
3 Ahmad Tafsir, Pendidikan Agama Dalam Keluarga, (Bandung: Remaja Rosdakarya, 2002), 1.

${ }^{4}$ Amirullah Syarbini, Pendidikan Karakter Berbasis Keluarga: Studi Tentang Model Pendidikan Karakter dalam Keluarga Perspektif Islam, (Yogyakarta: Ar-Ruzz Media, 2016), 13.
}

muda guna menjauhi praktik korupsi, kolusi, dan nepotisme di masa akan datang atau kelak ketika sudah menjadi satu bagian dari masyarakat. Untuk itu dalam rangka mencetak generasi-generasi pesantren yang mempunyai outcome yang baik, maka harus ditopang dengan eksistensi aktivitas pembelajaran yang bermutu dan berkualitas. Salah satu di antara menciptakan kualitas pembelajaran yang bermutu, maka seorang pendidik sangat penting memiliki kompetensi pengelolaan kelas yang mempuni.

\section{PEMBAHASAN}

\section{Dinamika Pendidikan Pesantren dan Definisi Pengelolaan Kelas}

Pesantren tidak akan pernah lekang dengan akar histografi pendidikan di Indonesia. Sepak terjang pendidikan Indonesia sangat diwarnai oleh eksistensi pendidikan pesantren, bahkan jauh sebelum negara Indonesia memproklamirkan kemerdekaannya. Awal mula lahirnya pesantren di Indonesia berkat tangan mulia dan dakwah kanjeng Sunan Ampel. Beliau mendirikan pesantren di daerah Ampelan dan dari sinilah dai-dai terkemuka tercipta serta menyebar luas ke seantero Nusantara. ${ }^{5}$ Sistem pembelajaran yang dipakai di pesantren ialah semacam halaqah, bandongan atau wetonan, dan sorogan. Mayoritas pesantren identik dengan kegiatan belajar-mengajar antara guru dan murid yang menggunakan kitab-kitab klasik berwarna kuning. Namun pada perkembangannya, sistem pembelajaran pesantren di Indonesia mengalami beberapa perubahan yang menyesuaikan terhadap perkembangan zaman.

Pesantren yang mentransformasikan kurikulumnya pada aspek modernitas disebut sebagai pesantren modern. Pesantren modern lebih mengutamakan atau mengedepankan penggunaan absensi dalam aktivitas pembelajarannya. Semua aktivitas kehadiran murid selama pembelajaran ditulis dan dicatat sedemikian rupa. Bagi santri yang tidak hadir akan ditulis tidak hadir, sebaliknya, bagi santri yang hadir akan ditulis hadir ketika mengikuti pembelajaran. Fasilitas pembelajaran di pesantren modern pun lebih komplit, seperti penggunaan kelas

\footnotetext{
${ }^{5}$ Moh. Nawafil dan Hafifuddin Nur, "Pendidikan Indegenous Ala Pesantren Untuk Memperkokoh Karakter Generasi Milenial", Edupedia: Jurnal Studi Pendidikan dan Pedagogi Islam, Vol. 5, No. 1, (Juli, 2020), 19.
} 
dengan fasilitas LCD Proyektor, smart board, AC, dan berbagai fasilitas modern penunjang lainnya. Namun, pesantren yang tetap eksis menggunakan sistem balaqah, bandongan atau wetonan dan sorogan, tanpa mengadopsi pernak-pernik kegiatan pembelajaran modern disebut sebagai pesantren klasik. Namun kedua pesantren tersebut sama-sama memiliki ciri khas tersendiri dalam mencetak out-put lulusannya.

Out-come lulusan yang dapat membawa perubahan dan kontribusi bagi bangsa dan negara, penting sekali diperhatikan. Sebab demikian, perlu menciptakan aktivitas pembelajaran yang lebih bermakna dan dapat menghasilkan peserta didik berdaya guna tinggi. Salah satu langkah untuk mewujudkan hal tersebut adalah dengan cara membuat suasana kelas yang penuh dengan ide kreatif, inovatif, kondusif dan efektif melalui kemampuan guru dalam manajemen kelas. Pada dasarnya, lingkungan kelas dapat juga dikatakan sebagai lingkungan belajar. Antara lingkungan belajar dan lingkungan kelas bertumpu pada perbedaan cakupan. Jika lingkungan belajar memiliki cakupan interpretasi yang masih luas, akan tetapi kalau lingkungan kelas sudah memiliki cakupan yang spesifik, yakni hanya tertuju pada satuan kelas itu sendiri. Pada esensinya antara lingkungan belajar dan lingkungan kelas sama-sama bertujuan menciptakan suasana dan proses pembelajaran yang adaptif terhadap peserta didik.

Terdapat dua kata dalam terminologi pengelolaan kelas, yakni pengelolaan dan kelas. Asal kata dari pengelolaan ialah "kelola", mendapat imbuhan awalah "pe" dan akhiran "an". Pengelolaan disebut juga sebagai manajemen. Asal kata dari manajemen ini adalah berasal dari bahasa inggris yakni "management" dengan arti pengelolaan, tata pimpinan, dan tata pelaksanaan. ${ }^{6}$

Secara general, manajemen didefinisikan sebagai pengadministrasian, pen-setting-an, atau sebuah tindakan dalam merangkai suatu kegiatan. Sedangkan seseorang yang berkumpul dalam suatu ruangan yang terdiri dari beberapa kelompok guna melaksanakan kegiatan pembelajaran serta memperoleh teaching material dari seorang pendidik,

\footnotetext{
${ }^{6}$ John M. Echols dan Hassan Shadily, Kamus Inggris Indonesia : An English-Indonesian Dictionary, Jakarta: Gramedia Pustaka Utama, 2005), 417.
}

maka dinamakan sebagai kelas. Jadi, kelas merupakan suatu ruangan yang digunakan untuk aktivitas pembelajaran antara guru dan siswa dalam mencapai tujuan pengajaran yang telah ditetapkan. ${ }^{7}$ Sebuah usaha yang tersistematis dan terstruktur untuk mencapai tujuan tertentu dalam proses kegiatan pembelajaran disebut pengelolaan kelas. ${ }^{8}$ Benang merahnya dari pengertian pengelolaan kelas ialah sebuah konfigurasi yang terjadi di dalam kelas guna kepentingan pengajaran atau pun dalam mewujudkan tujuan pembelajaran. Oleh karena itu, berdasarkan dari uraian tersebut maka pengelolaan kelas menjadi sangat penting untuk dipahami secara benar bagi siapa saja yang ingin menerjunkan dirinya di dalam area pendidikan.

Aktivitas pengelolaan kelas atau yang kerap disebut juga sebagai manajemen kelas berkaitan erat dengan segala kompetensi guru dalam mengatur kelas, sehingga nantinya bisa mendayagunakan potensi siswa untuk menuangkan segala ide-ide kreatifnya serta gagasannya pada saat aktivitas pembelajaran berlangsung. Jika seorang guru paham betul dalam tata cara mengelola kelas yang baik, maka implikasinya ialah pada pengalokasian waktu yang efesien dalam melaksanakan segala bentuk kegiatan yang berkenaan dengan kurikulum. Selain itu dana yang digunakan tidak habis secara cuma-cuma, artinya penggunaan dana memang benar-benar tepat sasaran dalam mencapai tujuan pembelajaran.

\section{Tujuan Pengelolaan Kelas}

Pada dasarnya terdapat beberapa aliran pendidikan sebagai bekal untuk memahami tujuan manajemen kelas secara komprehensif. Aliran pendidikan yang diusung oleh seorang filsuf Jerman ternama, yakni Schopenhauer, menyatakan bahwa perkembangan seorang anak didik dipengaruhi oleh faktor bawaan dari semenjak lahir. Adapun faktor lingkungan sangat minim pengaruhnya terhadap perkembangan peserta didik di masa mendatang. Jadi, anak didik yang awal mulanya baik, maka dapat dipastikan di masa mendatang akan baik pula. Sebaliknya, jika peserta didik dari sejak kecil memiliki

\footnotetext{
7 Syaiful Bahri Djamarah, Strategi Belajar Mengajar, Jakarta: Rineka Cipta, 2014), 196.

${ }^{8}$ Syaiful Bahri Djamarah, Strategi Belajar Mengajar, Jakarta: Rineka Cipta, 2014), 198.
} 
pembawaan buruk, maka selamanya dia akan buruk. Aliran yang demikian adalah aliran Nativisme. ${ }^{9}$ Upaya pendidikan yang sejatinya mengubah tingkah laku atau paradigma berpikir peserta didik dari basic step menuju high step ialah kurang berpengaruh dalam aliran ini, sebab keberhasilan dari perkembangan peserta didik ditentukan oleh faktor bawaan bukan faktor dari luar. Pada aliran ini pula, aktivitas pembelajaran dilakukan berdasarkan bakat dari seorang peserta didik. Jika pendidikan peserta didik sesuai dengan bakat yang dimilikinya, tentu profesionalitas dalam bidang ilmu yang ditekuninya akan mudah didapat. Akan tetapi bila bakat yang dimiliki dan pendidikan yang diperoleh tidak sesuai, maka pendidikan menjadi suatu hal yang sia-sia belaka.

Adapun lawan berkenaan dengan aliran tersebut di atas adalah aliran empirisme. John Locke adalah tokoh pengusung utama dalam aliran ini. Aliran empirisme sangat menekankan pada pengalaman peserta didik yang dialaminya guna meningkatkan perkembangan berpikir. Pangalaman empirik merupakan faktor inti dari aliran ini. Bakat bukan menjadi faktor yang penting dalam mempengaruhi perkembangan berpikir peserta didik. ${ }^{10}$ Pembawaan sejak lahir yang dimiliki anak didik tidak ada gunanya dibandingkan faktor lingkungan yang dimiliki. Jika seorang anak didik berada di lingkungan baik, maka kedepannya peserta didik akan menjadi baik pula. Namun, jika peserta didik berada pada lingkungan yang buruk, artinya terdapat multi negative factor yang akan mempengaruhi peserta didik, maka hasilnya pun tidak akan jauh berbeda dengan pengaruh lingkungan yang dialami. Padahal juga banyak seorang anak yang sukses dan meraih mimpinya sebab berangkat dari bakat yang mereka miliki.

Perseteruan kedua aliran tersebut dapat diintegrasikan dengan adanya aliran konvergensi. Aliran ini diusung oleh william stern, salah satu tokoh pendidikan Jerman terkemuka pada tahun 1871-1939. Menurut Stern, peserta didik dalam mengembangkan segala potensi dirinya sangat berkaitan erat dengan adanya faktor lingkungan dan bakat. Cikal bakal lahirnya aliran konvergensi ini adalah aliran nativisme dan aliran empirisme itu sendiri. Sebab

\footnotetext{
9 Abdul Kadir, Dasar-Dasar Pendidikan, (Jakarta: Kencana, 2012), 127.

${ }^{10}$ Syafril dan Zelhendri Zen, Dasar-Dasar Imu Pendidikan, (Jakarta: Kencana, 2017), 33.
}

demikian, aliran konvergensi merupakan aliran yang dapat mengkombinasikan antara pengaruh lingkungan dan bakat dalam petualangan peserta didik menuju kesuksesan. Potensi lahiriah atau yang kerap kali disebut bakat sangatlah penting untuk mengembangkan perkembangan berpikir peserta didik di masa akan datang. Lingkungan pun demikian, memiliki kedudukan yang sama vital dengan bakat. Bakat yang dimiliki peserta didik sejak lahir tidak akan berdayaguna tanpa adanya dukungan lingkungan yang sesuai untuk perkembangan. Prinsip dari aliran konvergensi ini yakni eksistensi pendidikan sangatlah vital dilaksanakan dan pendidikan diartikan sebagai upaya pertolongan dari lingkungan dalam rangka mengembangkan potensi lahiriah peserta didik menjadi lebih baik serta sebagai upaya preventif akan hal-hal negatif. ${ }^{11}$

Dari uraian di atas, dapat diketahui bersama bahwa lingkungan yang baik sangat penting untuk menopang potensi lahiriah peserta didik, termasuk di antaranya adalah lingkungan kelas. Oleh karena itu pengelolaan lingkungan kelas sangat urgen dilakukan oleh pendidik. Secara general manajemen kelas adalah suatu upaya memfasilitasi bagi bermacam macam aktivitas pembelajaran siswa dalam lingkungan social, emotional, dan intellectual dalam kelas. Ketersediaan fasilitas sebagaimana hal tersebut di atas dapat mempengaruhi siwa belajar dan bekerja, terciptanya kepuasan sosial, disiplin diri, perkembangan kognitif, afektif dan psikomotorik serta apresiasi pada diri anak didik. Aktivitas pembelajaran yang efektif dan efisien dalam rangka membentuk peserta didik secara aktif bekerja dan mengembangkan potensi dirinya dengan runut dan tertib merupakan tujuan dari pengelolaan kelas. Menurut Suharsimi Arikunto tujuan pengelolaan lingkungan belajar yang berupa kelas adalah menjadikan setiap anak yang berada di dalam kelas dapat bekerja (berpikir, berinteraksi dan berpendapat) sehingga akan tercapai tujuan pengajaran secara efektif dan efisien. ${ }^{12}$

Pengelolaan kelas juga bertujuan untuk menciptakan suasana pembelajaran yang berbingkai interaksi komunikatif. Artinya, ketika aktivitas pembelajaran berlangsung, seorang guru diwajibkan

\footnotetext{
${ }^{11}$ Moh. Nawafil, Cornerstone of Education; Landasan-Landasan Pendidikan, (Yogyakarta: Absolute Media, 2018), 126.

${ }^{12}$ Suharsimi A., Dasar-Dasar Supervisi Pendidikan, Jakarta: Rineka Cipta, 2004), 53.
} 
mampu mengkonfigurasi segala kondisi apapun yang terjadi di dalam kelas supaya terbentuk two ways communication, yakni komunikasi dua arah antara guru dengan murid, murid dengan guru. ${ }^{13}$ Melalui two ways communication diharapkan proses belajar-mengajar dapat berlangsung dengan baik. Hal ini bertujuan untuk memudahkan sekaligus meringankan tugas guru atau wali kelas.

\section{Peran Guru dalam Strategi Pengelolaan Kelas}

Esensi dari proses pendidikan adalah proses belajar mengajar yang terjadi secara sengaja dan terencana. Proses belajar mengajar yang baik merupakan sebuah dasar dalam mewujudkan hakikat pendidikan. Salah satu indikator penting untuk mengetahui sejauh mana kualitas pendidikan tercapai maksimal ialah dengan melihat aktivitas pembelajaran yang dilakukan. Aktivitas pembelajaran dapat diwujudkan secara optimal apabila seorang guru mengupayakannya secara serius dan profesional. Sebab itu seorang guru merupakan kunci utama dalam menentukan keberhasilan proses belajar mengajar yang terjadi di dalam kelas. Kompetensi seorang pendidik harus ditingkatkan terus menerus untuk menopang kesuksesan pembelajaran bersama peserta didik.

Seorang pendidik, tidak baik jika kompetensi yang dimilikinya berujung stagnan, dalam artian tidak ada peningkatan dalam segi inofasi, kreasi dan hal-hal lain yang dibutuhkan guna mencapai tujuan pembelajaran. Kompetensi yang mempuni dari seorang pendidik sangat berkaitan pada kiprahnya dalam mengelola lingkungan belajar yang efektif dan efisien untuk menghantarkan peserta didik atau anak didiknya memperoleh hasil belajar yang memuaskan. Beberapa di antara peran guru dalam strategi pengelolaan kelas adalah sebagai demonstrator, sebagai manager kelas, sebagai mediator dan fasilitator, serta sebagai evaluator.

\section{Guru sebagai Demonstrator}

Kata demonstrator sendiri didefinisikan sebagai tauladan atau pemberi contoh kepada peserta didik. Jadi guru memiliki tugas untuk memberikan contoh atau suri tauladan yang baik sehingga nantinya

\footnotetext{
${ }^{13}$ Moh. Nawafil dan Junaidi, "Revitalisasi Paradigma Baru Dunia Pembelajaran yang Membebaskan", Jurnal Pendidikan Islam Indonesia, Vol. 4, No. 2, (April: 2020), 221.
}

dapat diimitasi oleh peserta didik dalam kehidupan sehari-harinya. ${ }^{14}$ Adanya pemberian contoh dan sikap yang baik dari seorang guru bertujuan untuk membentuk keperibadian luhur peserta didik melalui tiga aspek penting yakni kognitif, afektif dan psikomotorik. Guru merupakan sosok ideal untuk diamati dan ditiru berbagai kiprahnya oleh peserta didik, hal ini tidak bertolak belakang dengan contoh jika ada sebuah statement orang tua yang berlainan dengan statement seorang guru, maka mayoritas murid akan membela atau lebih mengukuhkan statement gurunya dibandingkan statement si orang tua. Hal demikian mengasumsikan bahwa seorang guru menjadi model bagi siswa untuk diteladani dari segala hal yang telah dilihat untuk kompleksitas kehidupannya. Berangkat dari demonstrator itulah seorang guru bisa menyampaikan tutur kata yang baik bagi siswanya, keteladanan yang luhur, rasa nasionalisme, dan kemampuan memecahkan suatu masalah.

\section{Guru sebagai Manager Kelas}

Jika dilihat artinya, kata manager memiliki makna pengelola atau pimpinan. ${ }^{15}$ Jadi manager kelas adalah seseorang yang berkuasa penuh untuk mengelola ruangan kelas. Skill mengelola kelas dengan baik merupakan suatu hal yang sangat penting bagi seorang guru, berangkat dari hal ini nantinya aktivitas pembelajaran dapat tercipta secara aktif dan menyenangkan. Ide-ide serta gagasan berlian peserta didik akan banyak terproduksi jika kondisi berpikirnya dan suasana belajarnya tidak mengganggu konsentrasi selama aktivitas pembelajaran. Jika guru minim menguasi keahlian ini, maka performance dan karismanya bisa jadi mengalami defisit temporal, serta aktivitas pembelajaran yang akan dilakukan menjadi hancur berantakan tanpa tujuan atau pun target. Manfaat lain jika guru benar-benar kompeten dalam mengelola kelas, peserta didik akan mempunyai motivasi yang besar dan merasa nyaman berada di dalam kelas guna mengikuti berbagai macam rangkaian aktivitas pembelajaran dengan jangka waktu yang tidak sebentar. Sebagai pengelola kelas, guru mempunyai fungsi-fungsi di antaranya ialah sebagai penyusun tujuan pembelajaran,

\footnotetext{
${ }^{14}$ Edi Sutarto, Sekolah Cinta; Menjadi Pemimpin dan Guru Hebat, (Jakarta: Erlangga, 2016), 66.

${ }^{15}$ John M. Echols dan Hassan Shadily, Kamus Inggris Indonesia : An English-Indonesian Dictionary, (Jakarta: Gramedia Pustaka Utama, 2005), 418.
} 
menciptakan sumber pembelajaran, memotivasi, mendorong, dan menstimulasi siswa. Terdapat dua macam motivasi yang harus diketahui oleh seorang guru, pertama adalah motivasi intrinsik yakni sebuah stimulus berupa spirit dan hal-hal lain yang dapat mendorong individu melakukan capaian tujuan kehidupannya. Motivasi intrinsik cenderung bersumber dari dalam diri seseorang, artinya tidak memerlukan faktor eksternal untuk menumbuhkan rasa keinginan mencapai suatu target. ${ }^{16}$ Sebagai contoh, terdapat siswa yang murni ingin belajar tanpa harus memikirkan faktor lain untuk menyemangati dirinya serta kemauan siswa tersebut adalah suatu hal yang cenderung timbul dari dalam dirinya tanpa ada paksaan orang lain yang mengkondisikan. $\mathrm{Hal}$ demikian dinamakan motivasi intrinsik. Namun apakah semua siswa secara alamiah mempunyai motivasi intrinsik, tentu tidak kesemuanya, oleh karena itu maka perlu kehadiran sorang guru untuk memberikan stimulus pada diri siswa guna mencapai beberapa target atau tujuan dalam diri individu seorang peserta didik. Pengaruh dari luar yang dapat merangasang atau pun mendorong siswa untuk mencapai tujuan hidupnya dengan spirit yang lebih dinamakan motivasi ekstrinsik. Adapun motivasi ekstrinsik adalah sebuah ajakan, suruhan, stimulus, rayuan, atau pun paksaan dari suatu pengaruh yang muncul di luar individu untuk melakukan sesuatu sebab adanya keadaan yang demikian. ${ }^{17}$ Seorang peserta didik mempunyai semangat membaca buku akibat sering melihat ayahnya gemar membaca buku atau pun mendapat arahan-arahan berkaitan dengan manfaat membaca buku sehingga tercipta rasa spirit baru dalam dirinya untuk selalu membaca seperti halnya ayahnya. Contoh tersebut ialah motivasi ekstrinsik, yakni seorang peserta didik yang memiliki semangat membaca buku akibat adanya motivasi dari faktor eksternal atau dengan kata lain ialah bukan bersumber dari dalam dirinya. Perbedaan mendasar dari motivasi ekstrinsik dan motivasi instrinsik adalah pada pengaruh dan sebab eksistensi hasrat dalam melaksanakan suatu hal. Sebagaimana definisi motivasi ialah subuah encouragement yang terdapat dalam diri individu baik berupa internal factor atau pun external factor dengan ditandai adanya

\footnotetext{
${ }^{16}$ Siti Sumarni, Psikologi Belajar, Jakarta: Raja Grafindo Persada, 2005), 35.

${ }^{17}$ Sobry Sutikno, Peran Guru dalam Membangkitkan Motivasi Belajar Siswa, (Depdiknas: Jakarta, 2007), 43.
}

hasrat dan minat, cita-cita dan harapan, kebutuhan dan dorongan, penghormatan serta penghargaan. ${ }^{18}$

Pemilihan sumber belajar yang tepat guna sangat memberikan dampak bagi petualangan siswa dalam memperoleh ilmu pengetahuan. Segala sesuatu yang berbentuk data, manusia, dan sebagainya yang bisa dimanfaatkan oleh peserta didik dalam menambah khasanah keilmuannya saat proses pembelajaran sehingga dengan mudah mencapai segala tujuan pembelajaran dan kompetensi yang telah ditetapkan disebut sebagai sumber belajar. Esensinya, sumber belajar dibuat untuk merangsang peserta didik supaya aktif dan tanggap saat mengikuti aktivitas pembelajaran. ${ }^{19}$ Definisi tersebut telah dikemukakan oleh Sudrajat akan terminologi yang pas terhadap sumber belajar. Adapun sumber belajar haruslah dapat digunakan dengan sebaik mungkin agar berfungsi dengan baik. Fungsi sumber belajar di antaranya adalah untuk ${ }^{20}$ :

a. Meningkatkan produktivitas kegiatan pembelajaran dengan cara mempercepat laju belajar dan membantu pendidik guna mengatur waktu secara efisien

b. Beban guru tidak terlalu banyak dalam menyiapkan materi dan mencari segala macam informasi yang berkaitan dengan bahan ajar, sehingga tugas guru lebih berfokus pada usaha pembimbingan peserta didik dan pembinaan dalam rangka merangsang motivasi siswa untuk belajar secara mandiri.

c. Memberikan kemungkinan pendidikan yang sifatnya lebih individual dengan jalan mengurangi kontrol guru yang kaku dan tradisional dan memberikan kesempatan kepada siswa untuk belajar sesuai dengan kemampuannya.

Menurut Sudrajat, jenis sumber belajar digolongkan menjadi dua yaitu:

\footnotetext{
${ }^{18}$ Hamzah B Uno, Model Pembelajaran Menciptakan Proses Belajar Mengajar yang Kreatif dan Efektif, (Jakarta: Bumi Aksara, 2007), 12.

${ }^{19}$ Asmuki dan Hasanah, "Pusat Sumber Belajar PAI dalam Dunia Pendidikan; Sebuah Kajian Kritis dan Pengembangannya", Edupedia: Jurnal Studi Pendidikan dan Pedagogi Islam, Vol. 5, No. 1, (Juli: 2020), 83.

${ }^{20}$ Azhar Arsyad, Media Pengajaran (Jakarta: PT Raja Grafindo Persada, 2000), 35.
} 
a. Learning resources by design, yakni sumber belajar yang secara khusus dirancang atau dikembangkan sebagai komponen sistem instruksional untuk memberikan fasilitas belajar yang terarah dan bersifat formal.

b. Learning resources by utilization, yakni sumber belajar yang tidak didesain khusus untuk keperluan pembelajaran dan keberadaannya dapat ditemukan, diterapkan, dan dimanfaatkan untuk keperluan pembelajaran.

Dari kedua jenis sumber belajar tersebut, sumber-sumber belajar meliputi pesan atau materi, orang, bahan ajar, alat atau perlengkapan, pendekatan/ metode/tekhnik dan lingkungan.

\section{Guru sebagai Mediator dan fasilitor}

Berangkat dari teori yang sangat lumrah didengungkan bahwa kemampuan peserta didik dalam memahami atau menagkap materi yang disampaikan adalah berbeda-beda, maka seorang guru dituntut untuk sekreatif mungkin dalam menyampaikan materi ajar sehingga materi tersebut nantinya adaptif untuk dicerna oleh beberapa siswa dengan kemampuan serta background yang berbeda. Beberapa peserta didik yang telah berada dalam satu kelas, tidak kesemuanya memiliki situasi serta kondisi berpikir yang sama. Sangat memungkinkan sekali terdapat siswa yang memiliki problem di keluarga sebelum berangkat ke sekolah, siswa yang lain mungkin tidak sempat menikmati sepiring nasi karena orang tuanya telah pergi ke pasar lebih dulu, siswa lain juga boleh jadi masih mengantuk sebab bergadang semalaman, dan beberapa juga ada yang malas pergi ke sekolah sebab bermain lebih mengasikkan daripada berada di kelas yang serba jenuh. Oleh karena itu pemilihan sumber belajar berupa bahan ajar yang inovatif sangat diperlukan di sini serta media interaktif guna menyampaikan materi kepada peserta didik. Skill dalam mengembangkan bahan ajar dan merancang media pembelajaran amat penting dimiliki oleh seorang guru sehingga nantinya dapat dimanfaatkan untuk menciptakan suasana kelas yang kondusif dengan berbagai aktivitas pembelajaran yang kreatif. Media pembelajaran adalah suatu alat atau bahan yang dapat digunakan untuk menghantarkan message berupa materi ajar dari seorang guru ke peserta didik. ${ }^{21}$ Media pembelajaran tentu berbeda dengan

\footnotetext{
${ }^{21}$ M. Suparman, Desain Instruksional Modern, (Jakarta: Erlangga, 2012), 19.
}

media pendidikan, dalam hal ini media pembelajaran sering disebut sebagai media for learning sedangkan media pendidikan sering disebut sebagai media education. Adapun media for learning adalah suatu aktivitas pembelajaran yang memfokuskan pada penggunaan media sebagai alat penghantar pesan yang berupa materi ajar dari seorang guru ke anak didik. Lain halnya dengan media education, yakni aktivitas pembelajaran atau penyampaian materi yang bertujuan untuk menjelaskan tentang media, artinya bahwa media di sini merupakan sebuah objek pembelajaran bukan sebagai alat atau pun penghantar pesan materi ajar. Penggunaan media pembelajaran dapat mengurangi hambatan-hambatan dalam proses pembelajaran, meningkatkan ketepatgunaan aktivitas belajar mengajar, menjaga kesimpangsiuran antara tujuan pembelajaran yang telah ditetapkan dengan materi ajar yang disampaikan, meningkatkan siswa dalam konsentrasi berpikir. Sebagaimana yang telah diketahui bersama bahwa komunikasi yang terjalin dengan baik sangat berdampak pada daya ingat siswa. Selama kurang lebih 3 jam penyampaian materi tanpa menggunakan media pembelajaran, artinya cuma mengandalkan verbatim saja menyebabkan daya ingat peserta didik hanya $70 \%$. Sedangkan jika seorang pendidik menyampaikan materi pembelajaran hanya menggunakan media visual, maka daya ingat peserta didik naik $2 \%$, yakni $72 \%$. Namun jika peserta didik memperoleh materi pembelajaran dari guru melalui media visual dan verbal maka daya ingat peserta didik mampu mencapai $85 \%{ }^{22}$ Lebih lanjut, Asyhar menyatakan bahwa tujuan dari penggunaan media pembelajaran adalah untuk merangsang hasrat dan perhatian siswa sehingga daya ingat peserta didik mengalami peningkatan. ${ }^{23}$ Adapun media pembelajaran berfungsi sebagai alat bantu pembelajaran yang bisa mempengaruhi lingkungan dan kondisi yang ditata oleh seorang pendidik. $^{24}$

\section{Guru sebagai Evaluator}

Rangkaian aktivitas pembelajaran yang telah dilakukan antara guru dan murid sangatlah penting untuk dinilai guna mengetahui hasil yang diperoleh.

\footnotetext{
${ }^{22}$ R. Asyhar, Kreatif Membangun Media Pembelajaran, Jakarta: Gaung Persada, 2011), 23.

${ }^{23}$ R. Asyhar, Kreatif Membangun Media Pembelajaran, (Jakarta: Gaung Persada, 2011), 26.

${ }^{24}$ Nunuk Suryani dan L. Agung S., Strategi Belajar Mengajar (Yogyakarta: Ombak, 2012), 9.
} 
Baik tidaknya output pembelajaran salah satunya bisa diketahui melalui evaluasi yang dilakukan. Rangkaian evaluasi terjadi sejak saat persiapan, tindakan, sampai tahap pemberian grade sekalipun. Hasil belajar siswa dapat ditelisik serta dianalis oleh seorang guru sebagai bahan pertimbangan dalam memberikan treatment kedepannya ialah melalui evaluation result baik berupa data kuantitatif atau pun kualitatif. Kegunaan dilakukannya evaluasi bukan hanya semata-mata untuk memberikan mark atau nilai tertentu kepada siswa secara simbolik saja, melainkan sebagai bahan atau acuan bagi guru untuk mengambil keputusan yang akan diberikan kepada siswa guna membenahi apa saja yang kurang tepat atau pun menyempurnakan segala hal yang telah dikerjakan dengan sebaik mungkin oleh peserta didik. Sebaiknya pula evaluasi dilaksanakan melalui tahap proses evaluasi dan hasil evaluasi dengan memanfaatkan beberapa kehadiran instrumeninstrumen yang berkaitan, secara terbuka.

\section{Prinsip-Prinsip dalam Manajemen Kelas}

Supaya dalam usaha mengelola kelas tidak mendapat hambatan atau rintangan yang berarti, maka prinsip-prinsip dalam mengelola menjadi suatu hal penting dipelajari sebagai rambu-rambu dalam menciptakan suasana kelas yang inovatif, kreatif, kondusif, dan menyenangkan. Pada upaya mengelola kelas, guru tidak serta-merta melakukan menurut kehendaknya sendiri tanpa mempertimbangan beberapa aspek yang telah dijelaskan secara teoritis. Oleh karena itu terdapat beberapa rambu yang akan menjadi pertimbangan bagi guru dalam mengelola kelas. Sebab demikian maka pendidik sangat perlu memahami prinsip-prinsip dalam manajemen kelas. Di antara prinsip-prinsip tersebut ialah sebagai berikut:

\section{Hangat dan Antusias}

Peserta didik cenderung menyukai guru yang bersinergi dan penuh semangat. Guru yang hangat dapat mengorganisasikan berbagai macam hal menjadi satu kesatuan yang menarik. Antusiasme guru yang tinggi berguna untuk mengimplementasikan segala macam tugas dengan kompleksitas rintangannya. Guru semacam ini tidak mudah mengeluh dan putus asa, dalam setiap kiprahnya akan selalu menemukan hal-hal beneficialbaru bagi siswanya. Kondisi kelas yang bagaimana pun dapat menjadi sebuah embrio yang akan memproduksi ratusan siswa cerdas, cekatan, pandai, rajin, disiplin dan segalanya, jika seorang guru minimal telah memiliki rasa antusias dan semangat dalam melaksanakan tugasnya sebagai tokoh utama aktivitas pembelajaran.

\section{Tantangan}

Tantangan yang berupa bahan, materi, media, cara kerja, verbatim dan serupanya dapat menyebabkan peserta didik giat dalam mengikuti aktivitas pembelajaran serta mengurangi tindakantindakan menyimpang lainnya. Guru yang selalu membuat tantangan-tantangan menarik pada peserta didik akan menciptakan aktivitas pembelajaran penuh dengan ide dan kemampuan memecahkan persoalan.

\section{Bervariasi}

Variasi adalah suatu hiasan yang akan menambah kecantikan estetis sebuah objek. Dalam rangka meminimalisir kejenuhan saat mengikuti aktivitas pembelajaran, maka variasi sangat diperlukan. Sebab dalam variasi terdapat tambahan hiasan yang menarik dilihat maupun dirasa. Variasi dalam sebuah kelas dapat membawa perubahan dari keadaan semula yang kurang menarik menjadi lebih menarik dengan berbagai taburan ide kreatif yang mengitarinya. Hal tersebut mempunyai korelasi jika dikaitkan dari sudut pandang terminologis kata variasi, yakni dalam Kamus Besar Bahasa Indonesia kata variasi adalah hasil perubahan atau tindakan dari keadaan semula, dan juga dapat diartikan sebagai selingan. Oleh karenanya penggunaan alat bantu atau media pembelajaran, metode dan gaya mengajar, serta pola komunikasi antara guru dan siswa butuh bervariasi guna menciptakan suasana kelas yang efektif.

\section{Keluwesan}

Guru adalah sosok yang akan ditiru oleh siswanya. Oleh karena itu segala tindak-tanduk guru menjadi cerminan dari suatu sikap peserta didiknya. Guru yang baik adalah guru yang mampu menghantarkan peserta didiknya tidak hanya pada sebatas mempunyai pemahaman secara kognitif, akan tetapi juga afektif dan psikomotorik. Sebab itulah maka sebuah iklim pembelajaran yang baik sangat perlu dibentuk guna mewujudkan situasi dan kondisi kelas yang efektif. 


\section{Tertuju pada suatu hal yang positif}

Aktivitas pembelajaran dan cara mengajar yang diberikan oleh guru kepada peserta didik harus berorientasi pada hal-hal yang positif. Penekanan hal-hal positif kepada peserta didik dapat menghindari perilaku peserta didik dari suatu hal yang negatif. Selain itu guru juga harus pandai dalam membentuk lingkungan belajar yang positif, sebab lingkungan adalah faktor yang tidak kalah penting dalam mempengaruhi tingkah laku siswa.

\section{Membentuk Karakter Disiplin}

Kemampuan mengembangkan disiplin diri bagi peserta didik merupakan tujuan akhir dari manajemen kelas. Sebab itulah motivasi guru untuk anak didik agar selalu menerapkan kedisiplinan harus selalu didengungkan. Namun untuk mengimplementasikan itu semua, terlebih dahulu seorang guru harus memberi teladan yang baik kepada anak didik berupa keteladanan dalam mengemban tanggung jawab, kepercayaam seseorang, menaati peraturan, dan pengendalian diri. Kunci dari kesuksesan penerapan kedisiplinan dalam kelas adalah sejauh mana guru tersebut juga menerapkan perilaku disiplin untuk dirinya, karena pada dasarnya peserta didik akan mencontoh atau meniru dari perilaku seorang guru.

\section{Pendekatan dan Konsep Penataan Ruang Kelas}

Manajemen kelas bukanlah masalah yang berdiri sendiri, tetapi saling berkaitan dengan berbagai faktor. Permasalahan anak didik adalah faktor utama yang sering menjadi perhatian guru tiada lain ialah untuk meningkatkan gairah siswa baik secara berkelompok maupun secara individual. Keharmonisan hubungan guru dan anak didik, tingginya kerjasama di antara siswa terbingkai dalam interaksi komunikatif. Lahirnya interaksi yang optimal bergantung dari pendekatan yang guru lakukan dalam rangka pengelolaan kelas. Berbagai pendekatan yang bisa digunakan oleh guru dalam pengelolaan kelas di antaranya adalah pendekatan kekuasaan, pendekatan ancaman, pendekatan kebebasan, pendekatan pengajaran dua arah, pendekatan kerja kelompok, pendekatan sosio-emisional, pendekatan pluralistik, dan pendekatan pemecahan masalah.
Menyusun ruang kelas yang bisa membangkitkan gairah peserta didik saat aktivitas pembelajaran ialah terdapat konsep-konsep yang harus diperhatikan betul oleh seorang guru. Konsentrasi peserta didik dan kenyamanannya dalam mengikuti penyampaian materi oleh guru di ruang kelas wajib diprioritaskan. Sebab dengan begitu pemahaman akan ilmu pengetahuan menjadi lebih banyak didapat. Pengaturan tempat duduk peserta didik saat mencerna materi di dalam kelas menjadi sangat penting dipertimbangkan, oleh karena itu pula bagaimana ruang gerak peserta disdik bisa diterapkan secara fleksibel dan leluasa saat aktivitas pembelajaran berlangsung. Tempat duduk yang dibuat berkelompok juga bisa membantu peserta didik cepat memahami materi karena memungkinkan adanya diskusi antar peserta didik, selain itu skill komunikasi interaktifnya dapat berkembang secara optimal. Dalam penataan space study, perlu memperhatikan beberapa hal yakni, visual dan ukuran kelas, tipe dan ukuran bangku atau meja peserta didik, kuantitas siswa dalam suatu kelas, kuantitas anak didik dalam setiap komunitas, jumlah komunitas dalam kelas serta susunan anak didik dalam kelompok (seperti anak didik yang mempunyai tingkat berpikir di atas rata-rata dengan anak didik yang mempunyai tingkat berpikir sedang, peserta didik laki-laki dan peserta didik perempuan). ${ }^{25}$

\section{SIMPULAN}

Sistem pembelajaran yang dipakai di pesantren ialah bermacam-macam seperti halaqah, bandongan atau wetonan, dan sorogan. Dalam perkembangannya, pesantren banyak memiliki perubahan sistem belajar maupun kurikulum sehingga lahirlah berbagai pesantren modern di Indonesia. Namun tujuan akhir setiap pesantren adalah mempersiapkan lulusan yang terbaik dan menjadi khairu ummah. Guna mewujudkan hal tersebut, maka seorang guru begitu penting memahami pengelolaan kelas, sebab pada dasarnya pengelolaan kelas adalah sebuah konfigurasi yang terjadi di dalam kelas guna kepentingan pengajaran atau pun dalam mewujudkan tujuan pembelajaran. Beberapa di antara peran guru

25 Syaiful Bahri Djamarah, Strategi Belajar Mengajar, (Jakarta: Rineka Cipta, 2014), 174. 
dalam strategi pengelolaan kelas adalah sebagai demonstrator, sebagai manager kelas, sebagai mediator dan fasilitator, serta sebagai evaluator. Supaya dalam usaha mengelola kelas tidak mendapat hambatan atau rintangan yang berarti, maka prinsip-prinsip dalam mengelola menjadi suatu hal penting dipelajari sebagai rambu-rambu dalam menciptakan suasana kelas yang inovatif, kreatif, kondusif, dan menyenangkan. Adapun pendekatan yang bisa digunakan oleh guru dalam pengelolaan kelas di antaranya adalah pendekatan kekuasaan, pendekatan ancaman, pendekatan kebebasan, pendekatan pengajaran dua arah, pendekatan kerja kelompok, pendekatan sosioemisional, pendekatan pluralistik, dan pendekatan pemecahan masalah.

\section{DAFTAR RUJUKAN}

A., Suharsimi. Dasar-Dasar Supervisi Pendidikan. Jakarta: Rineka Cipta, 2004.

Arsyad, Azhar. Media Pengajaran. Jakarta: PT Raja Grafindo Persada, 2000.

Asmuki dan Hasanah, "Pusat Sumber Belajar PAI dalam Dunia Pendidikan; Sebuah Kajian Kritis dan Pengembangannya", Edupedia: Jurnal Studi Pendidikan dan Pedagogi Islam, Vol. 5, No. 1, (Juli: 2020).

Asyhar, R. Kreatif Membangun Media Pembelajaran. Jakarta: Gaung Persada, 2011.

Djamarah, Syaiful Bahri. Strategi Belajar Mengajar. Jakarta: Rineka Cipta, 2014.

Echols, John M. dan Hassan Shadily. Kamus Inggris Indonesia : An English-Indonesian Dictionary. Jakarta: Gramedia Pustaka Utama, 2005.

Jalaluddin dan Abdullah Idi. Filsafat Pendidikan: Manusia, Filsafat dan Pendidikan. Depok: Raja Grafindo Persada, 2016.

Kadir, Abdul, Dasar-Dasar Pendidikan. Jakarta: Kencana, 2012.

Murtiningsih, Siti. Pendidikan Sebagai Alat Perlawanan: Teori Pendidikan Radikal Paulo Freire. Yogyakarta: Resist Book, 2004.

Nawafil, Moh. Cornerstone of Education; LandasanLandasan Pendidikan. Yogyakarta: Absolute
Media, 2018.

Nawafil, Moh. dan Hafifuddin Nur. "Pendidikan Indegenous Ala Pesantren Untuk Memperkokoh Karakter Generasi Milenial", Edupedia: Jurnal Studi Pendidikan dan Pedagogi Islam, Vol. 5, No. 1, (Juli, 2020).

Nawafil, Moh. dan Junaidi. "Revitalisasi Paradigma Baru Dunia Pembelajaran yang Membebaskan”, Jurnal Pendidikan Islam Indonesia, Vol. 4, No. 2, (April: 2020).

Sumarni, Siti. Psikologi Belajar. Jakarta: Raja Grafindo Persada, 2005.

Suparman, M. Desain Instruksional Modern. Jakarta: Erlangga, 2012.

Suryani, Nunuk dan L. Agung S. Strategi Belajar Mengajar. Yogyakarta: Ombak, 2012.

Sutarto, Edi. Sekolab Cinta; Menjadi Pemimpin dan Guru Hebat. Jakarta: Erlangga, 2016.

Sutikno, Sobry. Peran Guru dalam Membangkitkan Motivasi Belajar Siswa. Depdiknas: Jakarta, 2007.

Syafril dan Zelhendri Zen. Dasar-Dasar Ilmu Pendidikan. Jakarta: Kencana, 2017.

Syarbini, Amirullah. Pendidikan Karakter Berbasis Keluarga: Studi Tentang Model Pendidikan Karakter dalam Keluarga Perspektif Islam. Yogyakarta: ArRuzz Media, 2016.

Tafsir, Ahmad. Pendidikan Agama Dalam Keluarga. Bandung: Remaja Rosdakarya, 2002.

Uno, Hamzah B. Model Pembelajaran Menciptakan Proses Belajar Mengajaryang Kreatif dan Efektif. Jakarta: Bumi Aksara, 2007. 